\title{
REPRESENTATIVE BUREAUCRACY AND DISTRIBUTIONAL EQUITY: ADDRESSING THE HARD QUESTION
}

\author{
Kenneth J. Meier, Texas A\&M University \\ Robert D. Wrinkle, University of Texas Pan-American \\ J. L. Polinard, University of Texas-Pan American
}

All data and documentation to replicate this analysis are available from the authors. Address correspondence to: K.J. Meier, Dept. of Political Science, Texas A\&M University, College Station, TX 77843, email kmeierepolisci.tamu.edu 

Representative Bureaucracy and Distributional Equity:

Addressing the Hard Question

\begin{abstract}
Research on representative bureaucracy has failed to deal with whether or not representative bureaucracies produce minority gains at the expense of nonminorities. Using a pooled time series analysis of 350 school districts over six years, this study examines the relationship between representative bureaucracy and organizational outputs for minorities and nonminorities. Far from finding that representative bureaucracy produces minority gains at the expense of nonminorities, this study finds both minority and nonminority students perform better in the presence of a representative bureaucracy. This finding suggests an alternative hypothesis to guide research, that representative bureaucracies are more effective than their nonrepresentative counterparts.
\end{abstract}




\title{
Representative Bureaucracy and Distributional Equity: Addressing the Hard Question
}

\begin{abstract}
Despite initial skepticism that a bureaucracy widely representative of the people would make policy decision more responsive to the public (Meier and Nigro 1976), recent studies for both blacks and Latinos have found that under certain conditions passive racial and ethnic representation can produce active representation, that is policies that benefit minorities (Meier and Stewart 1991; Hindera 1993a; 1993b; Meier 1993; Seldon, Brudney and Kellough 1998). Such findings in widely differing bureaucracies from urban school districts to EEOC regional offices to Farmer's Home Administration loan programs generate some optimism simply because public bureaucracies are slowly becoming more representative in terms of race and ethnicity. At the same time, policy outcomes are often perceived as a zero-sum game, the gains of one group must be compensated for with losses from another. ${ }^{1}$ The fervor of the current affirmative action debate, for example, reflects the sincere beliefs by some whites that such policies take opportunities away from individuals simply because they are white (Eastland 1996). This study seeks to move the literature on representative bureaucracy to a direct consideration of such redistributional consequences. Given the inter-racial and inter-ethnic distributional concerns, empirical work on this question is desperately needed.
\end{abstract}


First, a brief review of representative bureaucracy theory is presented. The theory has evolved from a rather simple view of bureaucratic motivation to a fairly involved description of how individuals' values affect decisions in complex organizations. Second, we present a model based on this review and operationalize it using data from school districts in Texas. Because our concern is redistributional consequences, we estimate the impact of representative bureaucracy on both minority and Anglo students. These equity concerns are best illustrated through traditional regression analysis and a relatively recent analytical technique, substantively weighted least squares (SWLS). Third, using the results of this model, we suggest an alternative specification of how representative bureaucracies might influence public policy and a new hypothesis about representative bureaucracies.

\section{The Theory of Representative Bureaucracy}

Until ten years ago, the theory of representative bureaucracy was relatively simple. ${ }^{2}$ In every organization individuals who make decisions exercise discretion because organization rules cannot cover every contingency and because organizational socialization is rarely total (Downs 1967; Thompson 1967). If individuals are assumed to be utility maximizers, then individual bureaucrats with discretion are likely to use that discretion to make decisions that reflect their own values. One source of these values is the socialization process, and one of the most enduring 
relationships is the impact on race and ethnicity on values (Carmines and Stimson 1989). Representative bureaucracy, thus, suggests that if a bureaucracy is broadly representative of the public it serves, then it is more likely to make decisions that benefit that public (Thieleman and Stewart 1996).

The initial work examining a variety of value sources has been replaced by work focusing on values related to race. Not all policy decisions are likely candidates for influence by a representative bureaucracy. Bureaucrats must have discretion over decisions that are directly linked to race or ethnicity. Meier (1993) contends that representation is also enhanced by political support and that, in some cases, a critical mass is necessary. Seldon et al. (1998) introduce the concept of a representative role that mediates between one's background and one's policy decisions.

Quite clearly the work of Seldon et al. (1998), Hindera (1993a;1993b), Meier (1993) and Meier and Stewart (1991) demonstrate that minority access to positions in the bureaucracy influences policies in such a way as to benefit minority clientele. What they do not address are the distributional consequences. Are the results of representative bureaucracy achieved by taking benefits from some other group of clientele? Or might it be the case that representative bureaucracies are also more effective and thus minority gains are not at the expense of nonminority clientele? 


\section{An Operational Model of Representative Bureaucracy}

Educational institutions are ideal organizations to examine questions of representative bureaucracy. School systems are the nation's largest public employer; the modal bureaucrat is more likely to grade papers in Des Moines than shuffle them in Washington. Schools employ numerous professionals who are only loosely supervised; and, thus, discretion permeates the organization. School systems also generate a great deal of data so that the redistributional results of a representative bureaucracy can be assessed.

Our model of representative bureaucracy sets up what is called an education production function whereby student performance is a function of inputs to the organization and various policies. To this production function, we add measures of representative bureaucracy to determine if it matters given controls for other factors that affect performance. Because our concern is redistributional consequences, we run these models for both minority students and Anglo students.

Our units of analysis are 350 Texas school districts with at least 1000 students. To make sure that the districts are performing relatively similar functions, we further limit the analysis to districts with more than 10 percent but no more than 90 percent Anglo students, that is, multiracial districts. Data are available for six years from 1991 through 1996 so we pool 
these data resulting in a total of 2097 usable cases with no missing data. Pooled models are frequently affected by problems of serial correlation and heteroscedasticity. To control for serial correlation, a set of five dummy variables representing individual years is included in the model. ${ }^{3}$ Heteroscedasticity was assessed using the White test; corrections for the modest heteroscedasticity found did not alter the findings so the ordinary least squares results will be presented.

\section{Dependent Variable: Student Performance}

The state of Texas requires students in grades 3, 5, 8, and 10 to take standardized tests every year. The percentage of students who pass these tests in each school district is the dependent variable. Our measures include pass rates for all students, pass rates for minority students (blacks and Latinos), and pass rates for Anglos.

\section{Independent Variables: Controls}

To ensure that any relationships found between representation and student test scores are not spurious, a variety of other factors that influence education performance are included in the model. Because our interest is in testing aspects of the theory of representative bureaucracy, our discussion of these variables is brief. All are culled from the education literature and are frequently used in education production functions. Production functions typically include measures of environmental constraints, 
resources applied to the process, and district policies designed to improve performance. ${ }^{4}$

In the context of educational policy, poverty is a serious constraint on student performance. Poverty not only means students lack access to learning tools in the home (computers, educational toys, etc.) but is also correlated with a less stable and less supportive home environment (e.g., single parent households, high rates of teen pregnancy, and low educational expectations; Necochea and Cune 1996; Fuller et. al. 1996). Our measure of poverty is the percent of students who qualify for free or reduced-price meals in the school lunch program. ${ }^{5}$ The relationship to performance should be negative.

The relationship between expenditures and educational outcomes is one of the most contested relationships in educational policy. Examining a wealth of studies, Hanushek (1986; 1989; 1996) contends that there is no consistent relationship between money and student outcomes. Although this finding has been challenged by others (Hedges and Greenwald 1996), it remains the conventional wisdom. In recent longitudinal studies, however, Murray (1995), Evans, Murray and Schwab (1997), and Murray, Evans and Schwab (1995) found that districts that increased expenditures had improved performance afterward.

Three "expenditure" variables are included in the analysis-per pupil expenditures for instruction, average teacher salary, and percentage of money from state funds. Per pupil expenditures 
for instruction are used in preference to total per pupil spending because many Texas districts spend lavishly on extracurricular activities. Our concern is academic performance, so the spending measure should be based on classroom instruction. Education is personnel intensive, and most spending pays salaries of teachers and other staff. Higher salaries are perceived in economic theory as a way to attract better qualified persons to a profession (Hanushek and Pace 1995). Finally, state aid can be used to compensate for inequities in local tax bases. Although Texas is not known for redistributive educational policies and has a long history in court on this issue (San Antonio Independent School District V. Rodriquez, 1973; Edgewood Independent School District v. Kirby, 1987; See also Texas Research League 1986; Accountable Cost Advisory Committee 1986; Weiher 1988), greater funds from state governments can compensate for a meager local tax base. All relationships should be positive.

Education policies are adopted to influence student performance. Two such policies deal with the learning environment--class size and gifted classes. Although many studies indicate that only major changes in class size are effective, schools with smaller class sizes should have an advantage at the margin (see Pate-Bain et al. 1992; Nye et al. 1992; Hedges and Greenwald 1996; Hanushek 1996, 54). The measure is the number of students per teacher in the district. Gifted classes are 
generally conceded to be the best education that a school system offers (See DeHaan 1963). The number of students enrolled in gifted classes varies greatly across these districts (0 to 31\%), and greater access should result in better performance. Gifted classes should be positively related to performance, and class size should be negatively related.

Teachers are a crucial element in a student's educational environment. As a profession based on life-long learning, there should be some advantage to teachers with adequate experience, especially in multiracial districts. Our measure is the average years of teacher experience which should be positively related to student performance.

One factor we cannot control for is the innate abilities of the students, especially those abilities not correlated with poverty. A common strategy in such circumstances is to use exam scores by the same cohort of students for earlier grades (see Smith and Meier 1995). Unfortunately, the state of Texas only reported pass rates for individual grades for three of these years and never reported grade level data by race. While this suggests the models are somewhat underspecified, the levels of explained variation compare favorably to other models that do use a cohort control (Chubb and Moe 1990; Smith and Meier 1995).

\section{Independent Variables: Representation}

Bureaucratic representation is measured at the street level 
(Lipsky 1980)--the percentage of black and Latino teachers. Although intra-minority redistributional consequences are important in this area (Meier and Stewart 1991), in the interests of parsimony we limit our analysis to minority versus majority comparisons. This emphasis makes the combined percentage of both black and Latino teachers the appropriate measure. Representative bureaucracy hypothesizes that presence of minority teachers will improve the performance of minority students. The education literature suggests three ways minority teachers can do this: (1) minority teachers are more effective at teaching minority students (Moore and Johnson 1983, 472; Aaron and Powell 1982, 55); (2) minority teachers serve as role models for minority students (Cole 1986, 332); and (3) minority teachers mitigate the negative consequences of grouping, tracking, and discipline (Meier and Stewart 1991).

If minority teachers improve the education performance of minority students, then their impact on majority students should also be assessed. If minority teachers spend more time with minority students or teach in a different manner, then Anglo students could be worse off. The redistributional concerns of representative bureaucracy can be assessed directly by looking at the impact of minority teachers on Anglo students.

\section{Findings}

\section{Minority Representation and Distributional Equity}


Table 1 presents the production function model for all students, minority students, and Anglo students. Although the control variables are not our concern here, that they all are generally in the predicted direction and significant is reassuring in terms of model specification. The only anomaly is for teacher experience with positive coefficients for all students and Anglo students and a negative correlation for minority students.

\section{[Table 1 About Here]}

The relationship of concern is the slope for minority teachers. In the all students regression, a one percentage point increase in minority teachers is associated with a drop of .1113 points in the all student pass rate. That relationship along with the positive relationship for minority students--a one percentage point increase in minority teachers is associated with a .0614 percentage point increase in minority student pass rates--implies that there are redistributional tradeoffs, that minority students' gains come at the expense of nonminority students. Examining the Anglo regression, however, challenges this conclusion. A one percentage point increase in minority teachers is associated with a .0730 percentage point increase in the Anglo pass rate. This finding is strong support for the lack of redistributional consequences. In fact, a representative bureaucracy appears to benefit Anglos slightly more than it benefits minorities.

The puzzling finding for all students suggests that greater attention needs to be focused on the composition of the all 
student pass rates. With 98.6 percent of students falling into the categories of black, Latino or Anglo, the "other" students cannot account for this finding. Somewhat surprisingly, if one regresses Anglo and minority pass rates on the overall pass rate, one can account for only 77 percent of the variance (regression not shown).

The residuals from this regression, however, clarify the situation. Table 2 compares the districts with positive residuals to those with negative residuals. Clearly the difference between these two sets of districts cannot be found in the superior performance of any subset of students. Although the positive residual districts have a pass rate of 61 for all students compared to 49.3 for the negative residuals, the pass rates for Anglos and the pass rates for minorities are virtually identical in both sets of districts. What is different about the two sets of districts is their racial composition. The positive residuals have 73.4 percent Anglo students compared to 33.4 for the negative residual districts. So while each group of students performs the same, differences in the district's overall racial composition distinguish between the two sets of districts. The relationship for all students, therefore, is a statistical artifact reflecting the unequal racial distribution of students across these districts.

[Table 2 About Here] 


\section{Representative Bureaucracy as Nonlinear}

The residual pattern along with the fact that the positive residual districts have far fewer minority teachers (6.3\% versus $29.0 \%)$ suggests that the impact of representative bureaucracy might be nonlinear. Testing a hypothesis presented by Thompson (1982), for example, Meier (1993) found a nonlinear relationship between school administrators and student performance suggesting a critical mass was needed to have an impact.

Table 3 presents the results of a nonlinear estimation of representative bureaucracy (this table omits the coefficients for the other variables). These results support Thompson's argument. For all students, both the linear and squared minority teachers' terms are statistically significant. At low levels of minority representation, the impact on students is negative; but at higher levels it becomes positive. Taking the first derivative of these terms and setting them equal to zero predicts that the impact of minority teachers on all students will become positive at approximately 32.3\% minority teachers, a somewhat higher critical mass than Meier (1993) found in his nonlinear analysis.

[Table 3 About Here]

The equation in table 3 for minority students shows the same nonlinear pattern, negative at low levels and positive as a critical mass is reached. The threshold for a positive impact on minority students is much lower than that for all students, 
approximately $21.8 \%$ minority teachers. For Anglo students the relationship is linear; including the squared term adds no additional explanation to the equation. These findings, along with the lower levels of minority teachers in the "all students" dominated set of districts, strongly implies that there are no redistributional consequences of representative bureaucracy in these organizations. Anglo students actually do better in bureaucracies that are more representative of minorities; so minority student benefits do not come at the expense of nonminority students.

The size of impacts for minority teachers are not large, but then we should not expect them to be. Environmental factors have a dominant influence on school systems and student performance. Not every minority student is exposed to a minority teacher. Not all districts will exploit fully the talents of their teachers, including minority teachers. The difference in results for the all student rates and the minority and Anglo pass rates suggests that additional efforts to discriminate among these different bureaucracies are needed.

\section{A Substantively Weighted Analysis}

In a recent methodological development, Meier and Keiser (1996) argue that relationships between variables can vary across agencies. This position implies that ordinary least squares (OLS) analysis will not provide all the vital information in a policy- 
relevant situation. Because OLS seeks to generalize to the average case, it can miss those agencies that do better than average or any other policy relevant sets of agencies.

The basic process of substantively weighted analytical techniques (SWAT) is that cases of interest are weighted more heavily than cases of less interest. One form of SWAT, substantively weighted least squares (SWLS), starts with an OLS regression and then designates a set of cases that are selectively downweighted in a series of regressions until the cases of interest are weighted as 1.0 and those not of interest are weighted .05 (Meier and Keiser 1996).

Because our concern is tradeoffs, organizations that produce more equitable results are those of interest. To measure equity, we divide the minority pass rate by that for Anglo students. This measure has a mean of .588 and a standard deviation of .117 (in the average district the odds of a minority student passing the exam are .588 the odds of an Anglo student). Our interest is in those districts that produce more equitable results so we select the top ten percent of districts on this scale (those above .734). We then run a series of regressions weighting the equity districts at 1.0 and decreasing the weight of the other districts in increments of .05 until a final regression with weights of 1.0 and .05 .

Another way to address the equity question is to simply use a dummy variable interaction between equity districts and the 
variable for minority teachers. SWLS has two advantages over this approach. First, it does not induce the large amounts of collinearity that an interaction does. Second, SWLS permits all slopes to vary, thus making the variable of interest compete against all other variables for explanatory power. The dummy variable approach produced similar conclusions to swLS for the linear specification, but suffered from too much collinearity to provide good nonlinear estimates. ${ }^{6}$

The final SWLS and dummy variable regression results appear in table 4. The first column presents swLS results for a linear specification. Comparing these coefficients with the findings in table 1 provides information on what these equity districts do different from what the nonequity districts do. For the all student pass rate the relationship remains negative but it ceases to be statistically significant. Equally important changes occur in the representation coefficients for the minority and Anglo pass rates. The minority coefficient increases from .0614 to.0968, approximately a 58 percent increase. The Anglo coefficient jumps dramatically from .073 to .187 , an increase of 156 percent. For those districts more concerned with equity, these relationships suggest that both minority and Anglo students benefit more than their cohorts in districts not concerned with equity. In such districts, even at low levels of representation there are no inter-racial redistributional consequences. The comparable dummy variable findings show similar results for minorities and Anglos 
(columns 3 and 4).

[Table 4 About Here]

The second column of table 4 reports the SWLS nonlinear specifications for the equity equation. Again the relationship for Anglos remains linear. For the minority pass rate the relationships are approximately the same as they are for OLS [See Table 3] suggesting that if the linkage is nonlinear it is the same in the equity districts as the other districts. For the all student pass rates, the coefficients are about half the size for the Anglo districts. While the nonlinear specification has slight gains, they are rather modest so the conservative conclusion is the relationship between minority representation and student performance is linear for those districts highly concerned with equity and that this relationship is much stronger than the relationship for all districts.

A visual depiction of the SWLS analysis for representative bureaucracy--that is, minority teachers--is found in Figure 1. This figure shows how the slopes change at different weights, as nonequity districts are downweighted. The impact of minority teachers on student pass rates changes dramatically for Anglo students, rising approximately 2.5 times in the final weighted regression. The impact on minority student pass rates also increases, although not as sharply, to almost 1.5 times the beginning slope. The change in the impact of minority teachers for the all students pass rate falls to zero as the nonequity 
districts are downweighted. These findings, again, suggest that, in districts with greater equity, minority teachers are associated with increased student performance for both Anglo and minority students.

$$
\text { [Figure } 1 \text { about here] }
$$

\section{Conclusion}

Representative bureaucracy is offered as a partial solution for reconciling the conflict between democracy and administration. Given inter-racial and inter-ethnic political tensions, empirical work on the redistributional consequences of representative bureaucracy is badly needed. This study of educational outcomes provides traditional OLS analyses along with the use of SWLS in a partial attempt to meet that need. SWLS allows an investigation into the differences between classes of cases based on performance (Meier and Keiser 1996). In this study the performance measure involves street-level bureaucrats (minority teachers) in equitable and non-equitable districts. The findings of both the SWLS and the OLS suggest that moving toward a more representative bureaucracy will not have outcomes detrimental to the established majority. Instead of minority students' gains coming at the expense of Anglo students, both groups benefit from higher levels of minority representation of street level bureaucrats--teachers--in the education system. There appear to be no redistributional consequences. 
This paper is the first study to explore redistributional consequences of representative bureaucracy using SWLS. It should not be the last. A virtual wealth of appropriate data sets are now available for investigation using this technique. The opportunity to identify the impact of changes in the bureaucracy in several settings and over time would determine whether distributional changes come at a cost to established interests. School districts, similar to all organizations, vary widely in how they take resources [inputs] and translate them into educated students [outputs]. On a substantive level, this study has established that equity districts translate inputs, particularly minority teachers, into outputs different from how nonequity districts do. The result is two specific findings. First, these representative bureaucracies do not benefit one group of students at the expense of another. Second, organizations vary so that even if future work does find redistributional consequences in standard OLS analysis, that analysis must be extended in a SWAT framework to determine if all bureaucracies produce the same patterns.

The lack of redistributional consequences which results because all groups of students are better off suggests a provocative new hypothesis for organizational studies: Representative bureaucracies are more effective at meeting their goals than nonrepresentative bureaucracies in similar circumstances. The underlying logic of this hypothesis rests on 
the notion that discriminatory personnel policies result in less able employees which, in turn, detrimentally affect agency performance. Representative bureaucracies do not erect such artificial barriers to organizational performance and thus will perform at a higher level than those with discriminatory hiring practices. The provocative nature of this hypothesis suggests that representative bureaucracies are to be preferred on both normative and empirical grounds. While this is clearly only a single study addressing one policy area, the findings and this logic suggest that the linkage between representative bureaucracy and performance has sufficient support to make it a credible hypothesis in future research. 


\section{References}

Aaron, Robert and Glen Powell. 1982. "Feedback Practices as a Function of Teacher and Pupil Race during Reading Group Instruction." Journal of Negro Education 51 (Winter): 50-59.

Accountable Cost Advisory Committee. 1986. "Accountable Cost Study and Recommendations of the Accountable Cost Advisory Committee to the State Board of Education." Austin, TX: Texas Education Agency •

Burtless, Gary. 1996. Does Money Matter? The Effect of School Resources on Student Achievement and Adult Success. Washington: Brookings.

Carmines, Edward G. and James Stimson. 1989. Issue Evolution: Race and the Transformation of American Politics. Princeton: Princeton University Press.

Chubb, John and Terry Moe. 1990. Politics, Markets and America's Schools. Washington: Brookings.

Cole, Beverly P. 1986. "The Black Educator: An Endangered Species." Journal of Negro Education 55 (Summer): 326-334. DeHaan, Robert F. 1963. Accelerated Learning Programs. Washington: Center for Applied Research in Education, Inc.

Downs, Anthony. 1967. Inside Bureaucracy. Boston: Little, Brown .

Eastland, Terry. 1996. Ending Affirmative Action: The Case for Colorblind Justice. New York: Basic Books. 
Edgewood Independent School District V. Kirby. Texas SupCt, No. C8353, (1989).

Evans, William N., Sheila E. Murray, and Robert M. Schwab. 1997. "Schoolhouses, Courthouses, and Statehouses After Serrano." Journal of Policy Analysis and Management 16 (Winter), 10-31. Fuller, Bruce, Costanza Eggers-Pierola, Susan D. Holloway, Xiaoyam Liang and Marylee F. Rambaud. 1996. "Rich Culture, Poor Markets: Why do Latino Parents Forego Preschooling?" Teachers College Record 97 (Spring):400-418.

Hanushek, Eric A. and Richard R. Pace. 1995. "Who Chooses to Teach (and Why)?" Economics of Education Review 14 (June) : 107-117.

Hanushek, Eric A. 1986. "The Economics of Schooling: Production and Efficiency in Public Schools." Journal of Economic Literature 24 (September) :1141-1177.

Hanushek, Eric A. 1996. "School Resources and Student Performance." In Does Money Matter? The Effect of School Resources on Student Achievement and Adult Success, ed. Gary Burtless. Washington: Brookings.

Hanushek, Eric A. 1989. "Expenditures, Efficiency, and Equity in Education: The Federal Government's Role." American Economic Review 79 (May):46-51.

Hindera, John. 1993a. "Representative Bureaucracy: Imprimis Evidence of Active Representation in the EEOC District 
Offices." Social Science Quarterly 74 (March): 95-108. Hindera, John. 1993b. "Representative Bureaucracy: Further Evidence of Active Representation in the EEOC District Offices." Journal of Public Administration Research and Theory 3 (October), 415-429.

Hedges, Larry V. and Rob Greenwald. 1996. "Have Times Changed? The Relation between School Resources and Student Performance." In Does Money Matter? The Effect of School Resources on Student Achievement and Adult Success, ed. Gary Burtless. Washington: Brookings.

Lasswell, Harold. 1936. Politics: Who Gets What, When, How? New York: McGraw Hill.

Lipsky, Michael. 1980. Street Level Bureaucracy. New York: Russell Sage Foundation.

Long, Norton. 1952. "Bureaucracy and Constitutionalism." American Political Science Review 46 (September), 808-818. Meier, Kenneth J. 1993. "Latinos and Representative Bureaucracy: Testing the Thompson and Henderson Hypotheses." Journal of Public Administration Research and Theory 3 (October): 393415.

Meier, Kenneth J. and Lael R. Keiser. 1996. "Public Administration as a Science of the Artificial: A Methodology for Prescription." Public Administration Review 56 (September/October): 459-466. 
Meier, Kenneth J. and Lloyd G. Nigro. 1976. "Representative Bureaucracy and Policy Preferences." Public Administration Review 36 (July/August), 458-469.

Meier, Kenneth J. and Joseph Stewart, Jr. 1991. The Politics of Hispanic Education. Albany: SUNY Press.

Moore, Helen A. and David R. Johnson. 1983. "A Reexamination of Elementary School Teachers' Expectations: Evidence of Sex and Ethnic Segmentation." Social Science Quarterly 64 (September): 460-475.

Murray, Sheila E. 1995. "Two Essays on the Distribution of Education Resources and Outcomes." PhD. diss. Department of Economics, University of Maryland.

Murray, Sheila E., William N. Evans and Robert M. Schwab. 1995. "Money Matters After All: Evidence From Panel Data on the Effects of School Resources." University of Kentucky and University of Maryland working paper: The Martin School. National Education Goals Panel. 1996. The National Education Goals Report: Building A Nation of Learners. Washington: U.S. Government Printing Office. Necochea, Juan and Zullmara Cune. 1996. "A Case Study of Within District School Funding Inequities." Equity \& Excellence in Education 29 (September): 69-77.

Nye, Barbara A., Jayne Boyd-Zacharias, B. Dewayne Fulton, and Mark P. Wallenhorst. 1992. "Smaller Classes Really are Better." 
American School Board Journal 179 (May): 31-33.

Pate-Bain, Helen, C.M. Achilles, Jayne Boyd-Zacharias, and Bernard McKenna. 1992. "Class Size Does Make a Difference." Phi Delta Kappan 74 (November) : 253-56.

San Antonio Independent School District v. Rodriquez. 411 U.S. 1 (1973) .

Seldon, Sally Coleman, Jeffrey L. Brudney, and J. Edward Kellough. 1998. "Bureaucracy as a Representative Institution: Toward A Reconciliation of Bureaucratic Government and Democratic Theory." American Journal of Political Science 42 (July): $716-$.

Smith, Kevin B. and Kenneth J. Meier. 1995. The Case Against School Choice. Armonk, NY: M.E. Sharpe.

Stimson, James. 1985. "Regression in Time and Space: A Statistical Essay." American Journal of Political Science 29 (November): 914-947.

Texas Research League. 1986. "Bench Marks for 1986-87 School District Budgets in Texas." Austin, TX: Texas Research League.

Thielemann, Gregory S. and Joseph Stewart, Jr. 1996. "A Demand Side Perspective on the Importance of Representative Bureaucracy." Public Administration Review 56 (March/April): $168-73$.

Thompson, James D. 1967. Organizations in Action. New York: 
McGraw Hill.

Thompson, Frank J. 1976. "Minority Groups in Public

Bureaucracies." Administration and Society 8 (August) :201226.

Weiher, Gregory R. 1988. "Why Redistribution Doesn't Work: State Educational Reform Policy and Governmental Decentralization in Texas." American Politics Quarterly 16 (April): 193-210. 
Table 1. Representative Bureaucracy: Its Distributional Aspects

\begin{tabular}{|c|c|c|c|}
\hline Independent Variable & All students & Minority students & Anglo \\
\hline \multicolumn{4}{|l|}{ Students } \\
\hline Minority Teachers & $\begin{array}{c}-.1113 \\
(.0158)\end{array}$ & $\begin{array}{c}.0614 \\
(.0191)\end{array}$ & $\begin{array}{c}.0730 \\
(.0172)\end{array}$ \\
\hline \multicolumn{4}{|l|}{ Expenditures } \\
\hline Instruction Funds K & $\begin{array}{l}.3564 \mathrm{~ns} \\
(.7933)\end{array}$ & $\begin{array}{l}3.2466 \\
(.9568)\end{array}$ & $\begin{array}{l}1.8146 \\
(.8656)\end{array}$ \\
\hline Teacher Salaries $\mathrm{K}$ & $\begin{array}{l}.7638 \\
(.1288)\end{array}$ & $\begin{array}{l}1.4008 \\
(.1553)\end{array}$ & $\begin{array}{l}.7008 \\
(.1405)\end{array}$ \\
\hline State Aid & $\begin{array}{l}.0230 \\
(.0091)\end{array}$ & $\begin{array}{l}.0639 \\
(.0109)\end{array}$ & $\begin{array}{l}-.0032 \mathrm{~ns} \\
(.0099)\end{array}$ \\
\hline \multicolumn{4}{|l|}{ Policy } \\
\hline Gifted Classes & $\begin{array}{l}.2827 \\
(.0473)\end{array}$ & $\begin{array}{l}.1778 \\
(.0570)\end{array}$ & $\begin{array}{l}.2642 \\
(.0516)\end{array}$ \\
\hline Class Size & $\begin{array}{l}-.7563 \\
(.1684)\end{array}$ & $\begin{array}{l}-.4024 \\
(.2031)\end{array}$ & $\begin{array}{l}-.4868 \\
(.1837)\end{array}$ \\
\hline \multicolumn{4}{|l|}{ Poverty } \\
\hline Percent Low Income & $\begin{array}{c}-.4090 \\
(.0140)\end{array}$ & $\begin{array}{c}-.2584 \\
(.0169)\end{array}$ & $\begin{array}{r}-.1648 \\
(.0153)\end{array}$ \\
\hline Teacher Experience & $\begin{array}{c}.3693 \\
(.1056)\end{array}$ & $\begin{array}{c}-.7589 \\
(.1273)\end{array}$ & $\begin{array}{c}.3633 \\
(.1152)\end{array}$ \\
\hline R-Square & .71 & .54 & .54 \\
\hline Standard Error & 6.47 & 7.80 & 7.06 \\
\hline $\mathrm{F}$ & 383.78 & 190.13 & 190.57 \\
\hline $\mathrm{N}$ & 2097 & 2097 & 2097 \\
\hline
\end{tabular}


All relationships significant at .05 except those marked ns. Numbers in parentheses are standard errors.

Dummy variables for individual years are not reported. 
Table 2. Comparing the Positive Residual Districts with the Negative Ones

Variable

Negative Residuals

Positive Residuals

Pass Rates

All students

49.3

61.0

Minority Students

39.5

40.3

Anglo Students

65.8

67.3

Percent of Students

Black

13.6

11.6

Latino

52.4

13.6

Anglo

33.4

73.4

$-$

Residuals from Regression of All Student Pass Rate on Minority and Anglo Pass Rates 
Table 3. The Nonlinear Impact of Representative Bureaucracy:

Distributional Consequences

\begin{tabular}{|c|c|c|c|}
\hline Independent Variable & All students & Minority students & Anglo \\
\hline \multicolumn{4}{|l|}{ Students } \\
\hline Minority Teachers & $\begin{array}{l}-.5254 \\
(.0372)\end{array}$ & $\begin{array}{l}-.3578 \\
(.0453)\end{array}$ & $\begin{array}{l}-.0816 * \\
(.0419)\end{array}$ \\
\hline Teachers Squared & $\begin{array}{c}.0081 \\
(.0007)\end{array}$ & $\begin{array}{l}.0082 \\
(.0008)\end{array}$ & $\begin{array}{l}.0030 \\
(.0007)\end{array}$ \\
\hline \multicolumn{4}{|l|}{ Expenditures } \\
\hline Instruction Funds K & $\begin{array}{l}1.1647 \mathrm{~ns} \\
(.7694)\end{array}$ & $\begin{array}{l}4.0646 \\
(.9377)\end{array}$ & $\begin{array}{l}2.1164 \\
(.8656)\end{array}$ \\
\hline Teacher Salaries $\mathrm{K}$ & $\begin{array}{l}.6993 \\
(.1245)\end{array}$ & $\begin{array}{l}1.3355 \\
(.1518)\end{array}$ & $\begin{array}{c}.6767 \\
(.1401)\end{array}$ \\
\hline State Aid & $\begin{array}{l}.0163 \mathrm{~ns} \\
(.0088)\end{array}$ & $\begin{array}{l}.0572 \\
(.0107)\end{array}$ & $\begin{array}{c}-.0057 \mathrm{~ns} \\
(.0099)\end{array}$ \\
\hline \multicolumn{4}{|l|}{ Policy } \\
\hline Gifted Classes & $\begin{array}{c}.2516 \\
(.0458)\end{array}$ & $\begin{array}{c}.1464 \\
(.0558)\end{array}$ & $\begin{array}{l}.2526 \\
(.0515)\end{array}$ \\
\hline Class Size & $\begin{array}{c}-.6071 \\
(.1631)\end{array}$ & $\begin{array}{c}-.2513 \mathrm{~ns} \\
(.1988)\end{array}$ & $\begin{array}{l}-.4310 \\
(.1836)\end{array}$ \\
\hline \multicolumn{4}{|l|}{ Poverty } \\
\hline Percent Low Income & $\begin{array}{c}-.3836 \\
(.0137)\end{array}$ & $\begin{array}{c}-.2327 \\
(.0167)\end{array}$ & $\begin{array}{c}-.1554 \\
(.0154)\end{array}$ \\
\hline Teacher Experience & $\begin{array}{l}.4087 \\
(.1021)\end{array}$ & $\begin{array}{c}-.7191 \\
(.1244)\end{array}$ & $\begin{array}{c}.3779 \\
(.1148)\end{array}$ \\
\hline R-Square & .73 & .56 & .55 \\
\hline Standard Error & 6.25 & 7.62 & 7.03 \\
\hline
\end{tabular}


F

$\mathrm{N}$

2097
192.52

179.44

2097

* $\mathrm{p}=.051$

All relationships significant at .05 except those marked ns. Numbers in parentheses are standard errors.

Dummy variables for individual years are not reported. 
Table 4. Alternative Representation Coefficients

\begin{tabular}{|c|c|c|c|c|}
\hline \multirow{2}{*}{ Interaction } & \multicolumn{2}{|c|}{ SWLS } & \multicolumn{2}{|c|}{ Dummy Variable } \\
\hline & Linear & Non Linear & Equity & Nonequity \\
\hline \multicolumn{5}{|l|}{-} \\
\hline All students & $\begin{array}{l}-.0114 \mathrm{~ns} \\
(.0181)\end{array}$ & $\begin{array}{l}-.2416 \\
(.0480)\end{array}$ & $\begin{array}{l}.2291 \\
(.0156)\end{array}$ & $\begin{array}{l}-.1400 \\
(.0362)\end{array}$ \\
\hline All students2 & ---- & $\begin{array}{l}.0044 \\
(.0009)\end{array}$ & & \\
\hline \multirow{2}{*}{$\begin{array}{l}\text { Minority Students } \\
\text { ns }\end{array}$} & .0968 & -.3435 & .6189 & .0150 \\
\hline & $(.0223)$ & $(.0586)$ & $(.0428)$ & $(.0185)$ \\
\hline Minority students2 & ---- & $\begin{array}{l}.0085 \\
(.0011)\end{array}$ & & \\
\hline Anglo Students & $\begin{array}{l}.1870 \\
(.0183)\end{array}$ & $\begin{array}{l}.2028 \\
(.0489)\end{array}$ & $\begin{array}{l}.1265 \\
(.0405)\end{array}$ & $\begin{array}{l}.0686 \\
(.0175)\end{array}$ \\
\hline Anglo Students 2 & ---- & $\begin{array}{l}-.0003 \mathrm{~ns} \\
(.0009)\end{array}$ & & \\
\hline
\end{tabular}

SWLS Final Regression Estimates (Weights 1, .05) All coefficients significant except those marked ns. Standard errors in parentheses. 


\section{Notes}

1. Politics is, after all, the determination of who gets what, when, and how (Lasswell 1936). Politics thus implies conflict and redistribution. Despite the economics notion that there are Pareto optimal policy changes, the day-to-day conflict in the policy process suggests otherwise.

2. Several individuals have sketched out this theory, perhaps the first being Norton Long (1952). A recent presentation is Seldon et al. (1998).

3. Serial correlation was a significant problem. After a large drop in scores for these districts in 1992, they generally followed an upward trend. The use of dummy variables to correct for such problems is the traditional strategy for shallow pools such as this one (Stimson 1985).

4. This literature is far too large to cite comprehensively. See the extended bibliography in Burtless (1996).

5. Some of the other measures might also tap dimensions of socioeconomic status. Expenditures, because they are in part determined by the local tax base, are an example of an indirect measure of economic well being. 6. The tolerances for minority teachers, minority teachers squared and the two interaction terms were all below .15. The tolerance for minority teachers fell below .1. 